\title{
Obituaries
}

Obituaries should be submitted by email to Laura Pacey at I.pacey@nature.com.

All submitted obituaries should be 350 words maximum in length (apart from obituaries for past presidents of the BDA where the length should be $700-800$ words).

Content of the obituary is down to the individual author, and the approval of the family should be given for the obituary prior

to submission to the $B D J$.

\section{HARRY ALLRED}

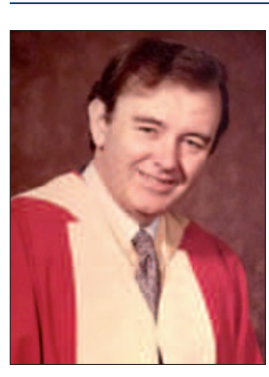

Harry Allred was born on 4 July 1929. He was educated at Leigh Grammar School and left at 16 , spending a year at Wigan Technical College having had a year out due to rheumatic fever. He met Brenda, through scouting and guiding, when they were 12 and 13 years old. They were married on 9 June 1954 and remained so for 56 years.

Harry's father was a 'plaster boy' at a dental practice and when he returned from service after WW1 he found that he had been added to the Dentists list. Harry studied dentistry at Manchester University and qualified in 1953. Following a house surgeon post and time in general practice, he became a teacher at the University of Manchester in 1956. In 1961 he moved to the London Hospital Medical College Dental School, becoming Professor of Conservative Dentistry (1969) and Dean of Dental Studies (1979), before retiring in 1994.

Throughout his academic career he had a strong belief that dentists should be involved in whole patient care, bringing to bear all their expertise for the benefit of the patient. Harry recognised the need to computerise various aspects of the working in the Dental School and was responsible, in collaboration with Fred Smales and Stuart Morganstein, for installing the very first networked computer system in any dental school in Europe and possibly the world.

Harry was the first Secretary of the BSRD and became President of the Association for Dental Education in Europe in
1986. He had positions with the University Grants Committee, the Joint Committee for Higher Training in Dentistry and WHO. He was the first Visiting Professor in Dentistry of the University of Otago in New Zealand.

One of his passions was the amateur operatic society, where Harry's beautiful tenor voice made many a public appearance. The Church played a large part in both Harry and Brenda's lives. In London All Hallows by the Tower became their spiritual home, where Harry became a church warden and Chair of the Wakefield Trust. Yet their diverse activities came to a halt when, in 2001, Harry had a stroke that changed his and Brenda's life for ever. It was Brenda's care and love that enabled Harry to enjoy the comforts of home for so long.

Harry died peacefully on 20 August 2012 and is survived by his daughter Dr Jo Allred.

Stuart Morganstein

\section{CHARLES WILLIAM DONALD JONES}

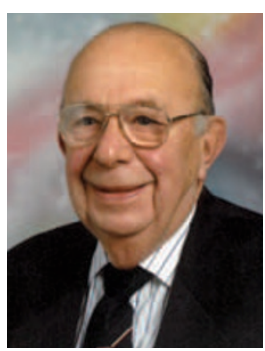

18 May 1926-

27 December 2012.

Charlie Jones was

a legend amongst

his many friends.

He was proud of

his Scots origins, describing himself as 'born in Edin-

burgh and dragged up in Glasgow'. In 1944, following his father's example he enlisted with the Royal Navy serving for over four years.

He graduated from Glasgow Dental School in 1954. His first job was with the Grenfell Mission at St Anthony to attend to the health needs of fisherman and their families in Newfoundland and
Labrador. Dentistry was within his duties, but he gained a much wider experience in anaesthetics and other departments that stood him in good stead for the rest of his career. His family note that the most important mission he accomplished was finding Barbara, who became his wife in 1957. By this time Charlie was working for Worcestershire County Council as a children's dental officer. Donal, their son, was born in 1960 but in 1962 tragedy struck when Barbara died.

In 1964 Charlie dared to ask one of the Health Department administrative assistants to a Valentine Ball and romance blossomed. For Donal's sake, they decided to get married at once and Audrey became wife to Charlie, mum to Donal and a year later gave Charlie a daughter, Marie (known as 'Poco') after which, as they say, they lived happily ever after.

Charlie rose to become Chief Dental Officer of Worcester and Hereford CC and in 1974 moved to Dudley Area Health Authority. In 1977 Charlie was proud to receive a Jubilee Medal as his father had. He held many offices, most notably as President of the Community Dental Services Group (1978-79). He became a Life Member of the BDA in 1986. He became a member of his local CHC serving as chairman in his last two years, finishing in 1993.

Most of his friends remember him for his legendary parties, splendid holidays and long weekends with the 'Midlands Mafia'. In all of these Charlie was the centre of the action.

To Audrey, Donal and 'Poco', and to Charlie's greatly loved grandchildren, we extend our sympathy, but do so in great thankfulness for all we have gained from Charlie's friendship.

Roger Bettles and David Hobbs 